\title{
Separation of the effects of denaturation and aggregation on whey-casein protein interactions during the manufacture of a model infant formula
}

\author{
Aoife M. Joyce ${ }^{1} \cdot$ André Brodkorb $^{2}$. \\ Alan L. Kelly ${ }^{1}$ • James A. O'Mahony ${ }^{1}$
}

Received: 10 June 2016 / Revised: 17 August 2016/Accepted: 3 September 2016 /

Published online: 10 October 2016

(C) INRA and Springer-Verlag France 2016

\begin{abstract}
Denaturation and aggregation of whey protein have been extensively studied but there is limited knowledge of their effects on processing properties of infant milk formulae (IMF) systems. In this study, the separate effects of denaturation and aggregation of whey protein on the physicochemical characteristics during processing of a model IMF were examined. Whey protein solutions $(8 \%, w / w$, protein) were pre-heated for $2 \mathrm{~min}$ at 72 or $85^{\circ} \mathrm{C}$, followed by addition of $2.2 \mathrm{mM}$ calcium $(\mathrm{Ca})(\mathrm{H}-\mathrm{BCa})$, or at $85^{\circ} \mathrm{C}$ after addition of the same level of $\mathrm{Ca}(\mathrm{H}-\mathrm{ACa})$, to give pre-treated whey protein for inclusion in three model IMF systems, encoded as H-72-BCa, H-85-BCa and H-85-ACa, respectively. Unheated control samples without (UH-C) and with (UH-C-Ca) added Ca were also prepared. Model IMF systems $(5.2 \%, w / w$, protein, 60:40 whey protein:casein ratio, $\mathrm{pH} 6.8)$ were then prepared incorporating these pre-treated whey protein ingredients and subjected to lab-scale high-temperature short-time (HTST) heating at $85{ }^{\circ} \mathrm{C}$ for $2 \mathrm{~min}$; whey protein denaturation was $>81.2 \%$ in all samples after HTST. Aggregation of whey protein resulted in a significantly $(P<0.05)$ higher viscosity in sample $\mathrm{H}-85$-ACa (8.3 mPa.s) compared to UH-C (4.0 mPa.s), and measurement of $\mathrm{Ca}$ ion concentration on heating showed that $\mathrm{Ca}$ ions enhanced whey protein aggregation, resulting in larger mean protein particle size. The results also suggest that pre-heating of whey protein had a preventative effect on aggregation of protein during HTST of IMF. This study clearly showed that aggregation is more influential than denaturation in determining viscosity development during HTST treatment of IMF, and that such viscosity development can be controlled by altering protein-protein interactions using, for example, pre-heat treatment of whey protein ingredients.
\end{abstract}

James A. O’Mahony

sa.omahony@ucc.ie

1 School Of Food And Nutritional Sciences, University College Cork, Cork, Ireland

2 Teagasc Food Research Centre, Moorepark, Fermoy, Co. Cork, Ireland 
Keywords Whey protein · Denaturation $\cdot$ Aggregation $\cdot$ Viscosity $\cdot$ Heat stability $\cdot$ Infant formula

\section{Introduction}

Whey proteins are widely-used, versatile, functional food ingredients that have a good nutritional profile with specific physiological properties (Madureira et al., 2010) and are used in products such as infant milk formulae (IMF). Matching the whey protein:casein ratio of 60:40 of human milk is one challenge in formulating IMF, as bovine milk has a ratio of 20:80. Thus, powders such as whey protein isolate, with protein content $\geq 85 \%$, can be incorporated as ingredients into formulations in order to achieve a wheydominant protein profile (Eugenia Lucena et al., 2006). The major proteins in whey are $\beta$-lactoglobulin $(\beta$-lg) and $\alpha$-lactalbumin $(\alpha$-lac). Of these, $\beta$-lg represents $\sim 20 \%$ of total protein in bovine milk; it has two disulphide bonds and one free thiol group, which are deemed responsible for the irreversible thermal aggregation and gelling properties of this protein (Brodkorb et al., 2016). $\alpha$-Lac has a single polypeptide chain, containing four disulphide bonds, and has no free sulphydryl group; native molecules of $\alpha$-lac consist of two domains, a large $\alpha$-helical domain and a small $\beta$-sheet domain, which are connected by a calcium-binding loop (Permyakov and Berliner, 2000).

The mechanisms of denaturation and aggregation of whey proteins have been extensively studied (Roefs and de Kruif, 1994, Verheul et al., 1998, Oldfield et al., 1998) and reviewed recently (Wijayanti et al., 2014; Brodkorb et al., 2016). The mechanism of denaturation and aggregation of $\beta-\lg$ was first proposed by Mulvihill and Donovan (1987) to have two distinct stages; the initial stage is the unfolding of the globular protein at temperatures $>65{ }^{\circ} \mathrm{C}$, while the second stage involves irreversible association of the unfolded molecules to form complexes, i.e. aggregates. At temperatures exceeding $70{ }^{\circ} \mathrm{C}$, irreversible aggregation occurs, which results in the formation of two different types of aggregates: small aggregates which occur due to sulphydryl group interaction and/or disulphide interchanges, and large aggregates which are formed by non-specific reactions, not involving the interactions of sulphydryl groups.

Denaturation and aggregation have been shown to impact the functionality of whey proteins during processing of different whey protein-containing systems. It is known that, at whey protein concentrations $\geq 3.5 \%$, heating of whey protein-containing solutions such as whey beverages, to temperatures $\geq 75{ }^{\circ} \mathrm{C}$ results in denaturation and can cause unfavourable aggregation, which leads to fouling of heat exchangers (Davies et al., 1997), increased turbidity (Mulcahy et al., 2016) and sedimentation and gelation (Ryan et al., 2012). Therefore, it is of considerable importance to understand and control aggregation to improve the stability of whey proteins in nutritional beverage applications.

There have been multiple studies of the effects of incorporating denatured and aggregated whey protein in various dairy-based systems (Anema and Li, 2003, Donato et al., 2007, Donato and Guyomarc'h, 2009), the effect of denatured whey proteins and mineral addition on the formation of microgels (Schmitt et al., 2011) and the effects of soluble denatured whey proteins on beverage stability (Ryan and Foegeding, 2015). Previous studies from our research group have investigated the influence of temperature and ionic strength on whey protein denaturation and aggregation during thermal processing (Ooi, 2015) and the enhancement of heat stability of model IMF protein 
systems by increasing $\alpha$-lac: $\beta$-lg ratio (Crowley et al., 2016), but there is limited information on the effects of denaturation and aggregation of whey proteins on viscosity and processing properties of IMF systems.

The present study is a systematic evaluation of the influence of pre-denaturation and aggregation of whey proteins, to different extents, on viscosity and processing properties of a model infant nutritional product. The objective was to study the individual contributions of denaturation and aggregation of whey proteins to viscosity development during thermal processing in infant formula applications. The physicochemical properties (i.e. protein particle size, surface hydrophobicity, accessible sulphydryl groups and colour) of a model IMF protein system, in which the whey protein component had been pre-denatured and/or aggregated, were evaluated before and after simulated high-temperature short-time (HTST) thermal processing, as would be applied during the industrial manufacture of IMF products.

\section{Materials and methods}

\subsection{Materials}

Whey protein isolate (WPI; BiPRO ${ }^{\circledR}$ ) was acquired from Davisco Foods International (Le Sueur, MN, USA), and low-heat skim milk powder (SMP) was supplied by Ornua (Fermoy, Ireland). The composition of both ingredients was determined using standard International Dairy Federation (IDF) methods. Total protein content (Kjeldahl method; IDF, 2014) was 89.4 and $34.6 \%$ for the WPI and SMP powders, respectively. The ash content (determined by dry ashing at $550{ }^{\circ} \mathrm{C}$ for $5 \mathrm{~h}$ ) was 1.97 and $7.6 \%$ for WPI and SMP powders, respectively. All other chemicals used were of analytical grade and obtained from Sigma-Aldrich (Dublin, Ireland).

\subsection{Preparation of WPI and SMP solutions}

Stock solutions $(8 \%, w / w$, protein) were prepared from WPI and SMP by low-speed magnetic stirring at $22{ }^{\circ} \mathrm{C}$ for $3 \mathrm{~h}$ in ultra-pure water. WPI solution was divided equally into five separate beakers and $2.2 \mathrm{mM}$ calcium was added, in the form of calcium chloride, with mechanical stirring at $22{ }^{\circ} \mathrm{C}$ to one subsample which was allowed to equilibrate for $2 \mathrm{~h}$, before the $\mathrm{pH}$ of all samples was adjusted to 6.8. The WPI and SMP solutions were then stored at $4{ }^{\circ} \mathrm{C}$ for $18 \mathrm{~h}$ to facilitate complete hydration.

\subsection{Pre-treatment of whey protein}

The WPI solutions were separately heat treated using an AR-G2 controlled-stress rheometer (TA Instruments, Crawley, UK) equipped with a starch pasting cell (SPC) geometry. Samples $(28 \mathrm{~mL})$ were subjected to a temperature profile as follows: initial temperature $\left(20{ }^{\circ} \mathrm{C}\right)$ was increased at a rate of $6{ }^{\circ} \mathrm{C} . \mathrm{min}^{-1}$ to reach the target temperature $\left(72\right.$ or $85^{\circ} \mathrm{C}$ ); samples were held at the target temperature for $2 \mathrm{~min}$ and then cooled to $10{ }^{\circ} \mathrm{C}$ at a rate of $6{ }^{\circ} \mathrm{C} \cdot \mathrm{min}^{-1}$ and held at $10^{\circ} \mathrm{C}$ for $8 \mathrm{~min}$. The samples were mixed at a constant shear rate of $15 \mathrm{~s}^{-1}$ throughout the heating, holding and cooling steps. Following heating, $2.2 \mathrm{mM}$ calcium was added, in the form of calcium 
chloride, with mechanical stirring at $22{ }^{\circ} \mathrm{C}$ for $2 \mathrm{~h}$, to three WPI subsamples (excluding the unheated control and sample to which calcium had been previously added) to ensure that all heated WPI samples had the same concentration of added Ca (Fig. 1).

\subsection{Preparation of model infant milk formulas}

Five model infant milk formula (IMF) samples were formulated to contain $5.2 \%, w / \mathrm{w}$, protein, of which the SMP contributed $50 \%$ of total protein and the remaining $50 \%$ consisted of WPI pre-treated as described in section 2.3. The model IMF solutions were stirred at $22{ }^{\circ} \mathrm{C}$ for $3 \mathrm{~h}$ at low speed to allow hydration and equilibration, after which the $\mathrm{pH}$ was adjusted to 6.8. The model IMF solutions were coded as follows on the basis of the pre-treatment applied to the WPI component; unheated control (UH-C), unheated control with added calcium (UH-C-Ca), sample heated at $72{ }^{\circ} \mathrm{C}$ before calcium was added (H-72-BCa), sample heated at $85{ }^{\circ} \mathrm{C}$ before calcium was added (H-85-BCa) and sample heated at $85{ }^{\circ} \mathrm{C}$ after calcium was added (H-85-ACa). A schematic representation showing formulation of the model IMF systems is provided in Fig. 1.

\subsection{Compositional analysis}

The macro chemical composition of each model IMF was determined using standard International Dairy Federation (IDF) methods and the mineral profile of each model IMF was determined by inductively coupled plasma-mass spectrometry (ICP-MS)

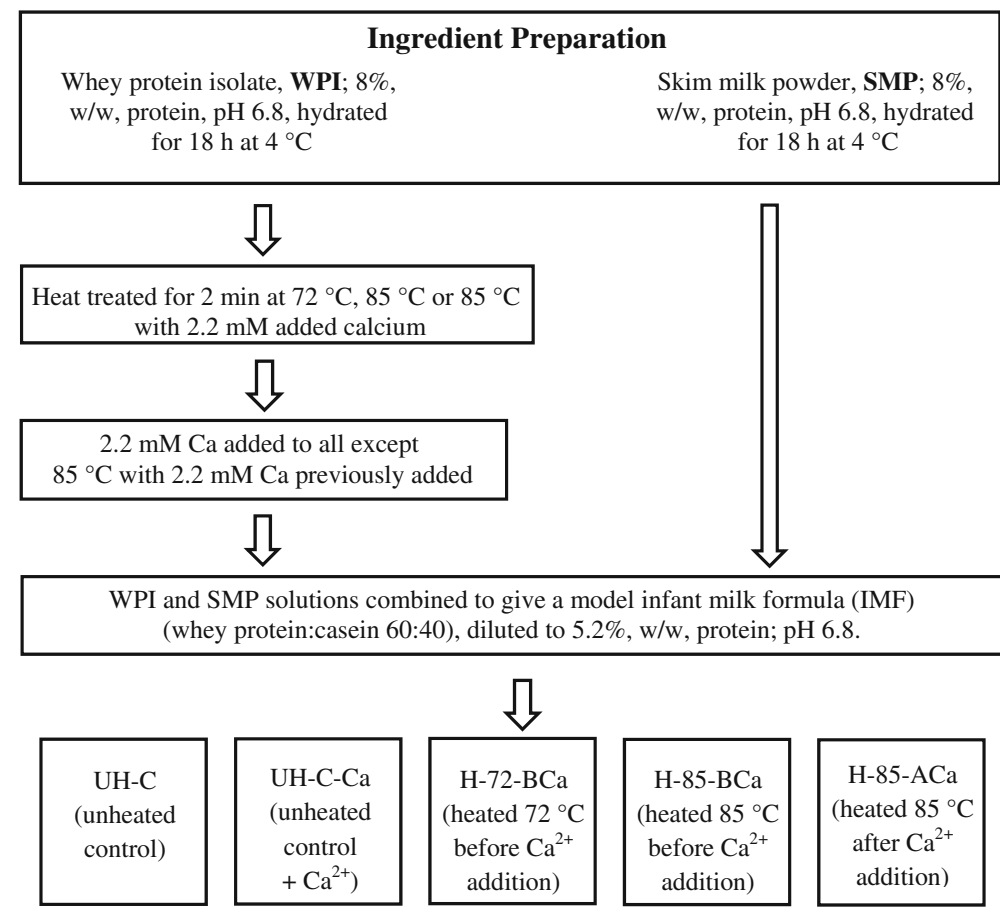

Fig. 1 Flow chart showing design of the study and formulation of model infant milk formula 
following the method of Herwig et al. (2011). The lactose content was determined by difference. Ionic calcium $\left(\mathrm{Ca}^{2+}\right)$ concentration was measured using a Titrando 907 autotitrator equipped with a polymer $\mathrm{Ca}^{2+}$ ion-selective electrode (Metrohm Ireland Ltd., Carlow, Ireland) as described by Crowley et al. (2014a), with the exception that calcium standards of 1, 2, 3, 4 and $5 \mathrm{mM} \mathrm{CaCl}_{2}$ were used.

\subsection{Heat stability and heat treatment of model infant milk formula}

The $\mathrm{pH}$ of each IMF sample was adjusted to 6.8 , if necessary, and the heat coagulation time (HCT) was measured at $140{ }^{\circ} \mathrm{C}$ using the method described by Crowley et al. (2015b). The model IMF samples were also subjected to a lab-scale heat treatment at $85^{\circ} \mathrm{C}$ for $2 \mathrm{~min}$, designed to simulate high-temperature short-time (HTST) processing, using an AR-G2 controlled-stress rheometer equipped with a starch-pasting cell geometry using the method described by Crowley et al. (2016). Viscosity was measured during this HTST treatment using an AR-G2 controlled-stress rheometer equipped with a $60 \mathrm{~mm}$ aluminium peltier parallel plate with a $1 \mathrm{~mm}$ geometry gap following the method described by Crowley et al. (2016). A layer of liquid paraffin was applied to the sample during the conditioning step at $20{ }^{\circ} \mathrm{C}$ to prevent dehydration during heating.

\subsection{Whey protein denaturation}

\subsubsection{Measurement of pH 4.6-soluble protein}

The $\mathrm{pH}$ 4.6-soluble fractions of samples were prepared following the method of O'Kennedy and Mounsey (2006) with some modifications, detailed as follows. Acetic acid $(5 \mathrm{~mL}$ of $10 \%, w / v)$ was added to each IMF solution $(50 \mathrm{~mL})$, which was then heated at $40{ }^{\circ} \mathrm{C}$ for $10 \mathrm{~min}$, after which $5 \mathrm{~mL}$ of sodium acetate $\left(1 \mathrm{~mol} . \mathrm{L}^{-1}\right)$ was added and the mixture was, held at $40{ }^{\circ} \mathrm{C}$ for a further $10 \mathrm{~min}$, and allowed to cool to $22^{\circ} \mathrm{C}$. The $\mathrm{pH}$ was then adjusted to 4.6 with either $10 \%(w / v)$ acetic acid or 1 mol. $\mathrm{L}^{-1}$ sodium acetate, if necessary, prior to centrifugation at $10,000 \mathrm{~g}$ at $22{ }^{\circ} \mathrm{C}$ for $20 \mathrm{~min}$. Whatman no. 542 filter paper (Whatman International Ltd., Maidstone, UK) was used to separate the filtrate from the supernatant. The extent of total whey protein denaturation was determined by Kjeldahl nitrogen analysis of the initial samples and the respective pH 4.6-soluble fractions (IDF, 2014).

\subsubsection{Reversed-phase high-performance liquid chromatography}

Prior to analysis, samples ( $\mathrm{pH} 4$ 4.6-soluble fractions, prepared as described above) were diluted 1:10 with solvent A $(0.1 \%$ TFA in $95 \%$ ultra-pure water with $5 \%$ reversedphase high-performance liquid chromatography (RP-HPLC) grade acetonitrile) and filtered with 0.2- $\mu \mathrm{m}$ low protein-binding membrane filters (Sartorius Stedium Biotech $\mathrm{GmbH}$, Göttingen, Germany). RP-HPLC analysis was performed using the method described by Huppertz et al. (2004) with some modifications. Samples $(20 \mu \mathrm{L})$ were applied to the column and eluted with $100 \%$ solvent A through the column for $5 \mathrm{~min}$ at a flow rate of $0.5 \mathrm{~mL} \cdot \mathrm{min}^{-1}$, followed by a linear gradient to $30 \%$ solvent $\mathrm{B}(0.1 \% \mathrm{TFA}$ in $95 \%$ HPLC-grade acetonitrile with 5\% ultra-pure water) for $5 \mathrm{~min}$. The eluent was increased linearly to $60 \%$ of solvent B over $30 \mathrm{~min}$ and maintained at $60 \%$ solvent B 
for $10 \mathrm{~min}$. The proportion of solvent B was then increased to $95 \%$ over $5 \mathrm{~min}$, held for $2 \mathrm{~min}$ and returned to $100 \%$ solvent A over $3 \mathrm{~min}$. To ensure re-equilibration of the system before injection of the next sample, $100 \%$ solvent A was eluted for $10 \mathrm{~min}$ between sample runs.

\subsection{Particle size distribution}

The particle size distribution of the model IMF solutions was determined by dynamic light scattering (DLS) using a Zetasizer Nano-ZS (Malvern Instruments Inc., Worchestershire, UK), equipped with Malvern Zetasizer software 7.02, following the method described by Crowley et al. (2016), except that samples were diluted 1:200 in a Ca-imidazole buffer ( $20 \mathrm{mM}$ imidazole, $5 \mathrm{mM} \mathrm{CaCl}_{2}, \mathrm{pH} 6.8$ ) as described by Anema (1997), in order to prevent micellar disintegration. The Z-average and polydispersity index (PDI) were recorded for each sample.

\subsection{Colour}

The colour of the unheated and heated model IMF solutions $(5.2 \%, w / w$, protein) was measured using a pre-calibrated Minolta Chroma meter CR-400 colorimeter (Minolta Ltd., Milton Keynes, UK) following the method described by Mulcahy et al. (2016).

\subsection{Accessible sulphydryl groups and surface hydrophobicity}

Protein samples were diluted in ultra-pure water $(\sim 18 \mathrm{M} \Omega)$ from 5.20 to $1.00 \%, w / v$, protein ( $\mathrm{pH} 6.8)$. The accessible sulphydryl (-SH) groups were measured following the method of Hoffmann and van Mil (1997) with modifications as described by Drapala et al. (2016). The level of accessible -SH groups was calculated using the molecular extinction coefficient for 5,5-dithio-bis-(2-nitrobenzoic acid) (DTNB) of $13,600 \mathrm{M}^{-1} \cdot \mathrm{cm}^{-1}$.

To measure the surface hydrophobicity, the method of Alizadeh-Pasdar and Li-Chan (2000) using the hydrophobic probe, 1-anilinonaphthalene-8-sulphonic acid ammonium salt (ANS), was followed with some modifications. Samples were diluted to 5 different protein concentrations in sample buffer $\left(0.1 \mathrm{~mol} . \mathrm{L}^{-1}\right.$ citric acid/0.2 mol. $\mathrm{L}^{-1}$ sodium phosphate, $\mathrm{pH} 6.8)$ as follows: $0.003,0.006,0.009,0.012$ and $0.015 \%(\mathrm{v} / \mathrm{v})$. Ten millilitres of each protein solution and $50 \mu \mathrm{L}$ of 0.008 mol. $\mathrm{L}^{-1}$ ANS were mixed and the fluorescence intensity was measured using a SFM 25 spectrofluorimeter (BioTek, Kontron Instruments, Saint-Quentin en Yvelines, France). The slope $\left(S_{0}\right)$ value (where in all cases $r^{2}$ value was $>0.98$ ) was used to express the surface hydrophobicity of proteins in each sample.

\subsection{Protein profile and molecular weight distribution analysis}

The distribution of protein in each model IMF solution was analysed by ultracentrifugation for $1 \mathrm{~h}$ at $100,000 \mathrm{~g}$ at $20^{\circ} \mathrm{C}$, to separate casein micelles (i.e. in the sediment phase) from proteins in the serum phase. The supernatants were considered representative of the serum phase of the model IMF solutions and were used to investigate the extent of whey protein-casein interactions in each model IMF solution. The protein 
profile of each ultracentrifugal supernatant was analysed by reversed-phase highperformance liquid chromatography following the method described by Crowley et al. (2015a).

Molecular weight distribution of protein in the ultracentrifugal supernatants was determined by size exclusion chromatography as described by Kehoe et al. (2011). Briefly, protein samples $(20 \mu \mathrm{L})$ were injected on two columns in series (TSKgel $\mathrm{G}^{2000 \mathrm{SW}_{\mathrm{XL}} \text { and } \mathrm{G} 3000 \mathrm{SW}} \mathrm{XL}, 7.8 \mathrm{~mm} \mathrm{ID}, 30 \mathrm{~cm}, 5 \mu \mathrm{m}$ particle size, Tosoh Biosciences LLC, USA) with a guard column (TSKgel SW $\mathrm{XL}_{\mathrm{XL}}, 6 \mathrm{~mm}$ ID $\times 4 \mathrm{~cm}$, $7 \mu \mathrm{m}$ particle size). An isocratic elution buffer $(20 \mathrm{mM}$ sodium phosphate buffer $\mathrm{pH} 7.0,0.03 \%, w / v$, sodium azide) was used at a flow rate of $0.5 \mathrm{~mL} \cdot \mathrm{min}^{-1}$. A molecular weight $\left(M_{\mathrm{w}}\right)$ calibration curve was created using molecular weight standards ranging from 14 to $670 \mathrm{~kg} \cdot \mathrm{mol}^{-1}$. Samples were filtered through $0.45-\mu \mathrm{m}$ low protein-binding Acrodisk ${ }^{\circledR}$ syringe filters (Pall Corporation, Port Washington, NY, USA) prior to injection on to the column. The protein content of the filtrates was determined by Kjeldahl nitrogen analysis to determine, by difference, the proportion of total protein that was not soluble.

\subsection{Statistical data analysis}

All pre-treated whey protein solutions and model IMF protein solutions were prepared in three independent trials and all analysis was conducted in triplicate. The data generated was subjected to one-way ANOVA using the MINITAB $^{\circledR}$ version 17 (Minitab Ltd., Coventry, UK) statistical analysis package. The Tukey comparison test was used to determine significant differences $(P<0.05)$ between mean values for different sample treatments.

\section{Results}

\subsection{Composition and heat stability of model infant milk formulas}

There were no significant differences $(P>0.05)$ in the levels of total solids, protein, lactose and ash of each model infant milk formula (IMF) protein system (Table 1); the fat content was $\leq 0.10 \%$ in all samples. In terms of the mineral profile of each IMF, the total calcium content was higher (significantly so for the H-85-BCa sample) in all calcium-fortified samples, compared with the control sample, UH-C. There were no significant differences in the concentrations of any of the other minerals between the samples. There were no significant differences in the concentration of ionic calcium $\left(\mathrm{Ca}^{2+}\right)$ between model IMFs UH-C, H-85-BCa and $\mathrm{H}-85-\mathrm{ACa}$, while the ionic calcium concentration was higher in samples UH-C-Ca and H-72-BCa.

The heat coagulation time (HCT) of each model IMF was measured at the $\mathrm{pH}$ value at which HTST was conducted (i.e. $\mathrm{pH}$ 6.8). The HCT was significantly lower for the unheated control sample with added calcium (UH-C-Ca; $6.38 \mathrm{~min}$ ) than the control with no added calcium (UH-C; $14.5 \mathrm{~min}$ ). Pre-heat treatment of whey protein in the WPI at 72,85 or $85^{\circ} \mathrm{C}$ after calcium was added resulted in even lower heat stability $(\mathrm{HCT}<2 \mathrm{~min}$ ) for the resultant model IMF. 
Table 1 Composition of model infant milk formulae prepared with whey protein treated as follows: unheated control (UH-C), unheated control with calcium added (UH-C-Ca) and samples heated at $72{ }^{\circ} \mathrm{C}$ before calcium was added $(\mathrm{H}-72-\mathrm{BCa})$, heated at $85^{\circ} \mathrm{C}$ before calcium was added $(\mathrm{H}-85-\mathrm{BCa})$ or heated at $85^{\circ} \mathrm{C}$ with added calcium $(\mathrm{H}-85-\mathrm{ACa})$

\begin{tabular}{lccccc}
\hline Component & UH-C & UH-C-Ca & H-72-BCa & H-85-BCa & H-85-ACa \\
\hline Total solids $(\%, w / w)$ & $8.89 \pm 0.25^{\mathrm{a}}$ & $8.92 \pm 0.23^{\mathrm{a}}$ & $8.90 \pm 0.05^{\mathrm{a}}$ & $8.87 \pm 0.35^{\mathrm{a}}$ & $8.89 \pm 0.35^{\mathrm{a}}$ \\
Protein $(\%, w / w)$ & $5.19 \pm 0.00^{\mathrm{a}}$ & $5.20 \pm 0.02^{\mathrm{a}}$ & $5.19 \pm 0.02^{\mathrm{a}}$ & $5.19 \pm 0.03^{\mathrm{a}}$ & $5.18 \pm 0.01^{\mathrm{a}}$ \\
Lactose $(\%, w / w)$ & $3.00 \pm 0.24^{\mathrm{a}}$ & $3.00 \pm 0.26^{\mathrm{a}}$ & $3.02 \pm 0.18^{\mathrm{a}}$ & $2.90 \pm 0.27^{\mathrm{a}}$ & $3.00 \pm 0.30^{\mathrm{a}}$ \\
Ash $(\%, w / w)$ & $0.63 \pm 0.03^{\mathrm{a}}$ & $0.67 \pm 0.03^{\mathrm{a}}$ & $0.61 \pm 0.02^{\mathrm{a}}$ & $0.69 \pm 0.06^{\mathrm{a}}$ & $0.63 \pm 0.04^{\mathrm{a}}$ \\
Calcium $\left(\mathrm{mg} . \mathrm{L}^{-1}\right)$ & $740 \pm 31.5^{\mathrm{a}}$ & $816 \pm 9.5^{\mathrm{ab}}$ & $803 \pm 11.3^{\mathrm{ab}}$ & $836 \pm 35.4^{\mathrm{b}}$ & $789 \pm 8.4^{\mathrm{ab}}$ \\
Ionic calcium (mM) & $1.57 \pm 0.02^{\mathrm{a}}$ & $1.87 \pm 0.08^{\mathrm{b}}$ & $1.84 \pm 0.03^{\mathrm{b}}$ & $1.60 \pm 0.07^{\mathrm{a}}$ & $1.55 \pm 0.04^{\mathrm{a}}$ \\
Phosphorus (mg.L $\left.{ }^{-1}\right)$ & $620 \pm 21.7^{\mathrm{a}}$ & $618 \pm 11.2^{\mathrm{a}}$ & $618 \pm 10.0^{\mathrm{a}}$ & $631 \pm 22.8^{\mathrm{a}}$ & $608 \pm 5.0^{\mathrm{a}}$ \\
Magnesium (mg.L $\left.{ }^{-1}\right)$ & $73.9 \pm 3.5^{\mathrm{a}}$ & $73.3 \pm 0.2^{\mathrm{a}}$ & $72.0 \pm 0.01^{\mathrm{a}}$ & $74.9 \pm 2.9^{\mathrm{a}}$ & $72.9 \pm 0.4^{\mathrm{a}}$ \\
Potassium $\left(\mathrm{mg} . \mathrm{L}^{-1}\right)$ & $1127 \pm 60.1^{\mathrm{a}}$ & $1113 \pm 15.0^{\mathrm{a}}$ & $1073 \pm 26.4^{\mathrm{a}}$ & $1125 \pm 27.6^{\mathrm{a}}$ & $1134 \pm 0.2^{\mathrm{a}}$ \\
Sodium $\left(\mathrm{mg} . \mathrm{L}^{-1}\right)$ & $573 \pm 16.5^{\mathrm{a}}$ & $572 \pm 16.1^{\mathrm{a}}$ & $549 \pm 1.0^{\mathrm{a}}$ & $584 \pm 11.2^{\mathrm{a}}$ & $578 \pm 19.7^{\mathrm{a}}$ \\
\hline
\end{tabular}

Results are means \pm standard deviations of data from at least three independent trials on freshly prepared samples

${ }^{\mathrm{a}, \mathrm{b}}$ Values within rows followed by different superscripts are significantly different $(P \leq 0.05)$

\subsection{Viscosity during thermal processing}

The viscosity of each model IMF was measured continuously during lab-scale HTST processing (Fig. 2). At the initial temperature of $20{ }^{\circ} \mathrm{C}$, there were no significant differences in viscosity between samples, with viscosity ranging from 2.44 to $5.81 \mathrm{mPa} . \mathrm{s}$ (Table 2). Upon heating, as the temperature increased to $85^{\circ} \mathrm{C}$, the viscosity of all samples decreased (Fig. 2). On holding at $85^{\circ} \mathrm{C}$, the viscosity increased and, on cooling to $5^{\circ} \mathrm{C}$, there was a further considerable increase in the viscosity of all samples, with the viscosity of the H-85-ACa sample $(8.32 \mathrm{mPa} . \mathrm{s})$ being significantly higher than that of all other samples after cooling to $5^{\circ} \mathrm{C}$. The viscosity after heating was higher than the viscosity before heating for all samples.

\subsection{Particle size before and after HTST}

Each model IMF sample had a broadly monomodal particle size distribution prior to HTST treatment, with mean particle size of 176-205 nm (Table 2), while sample H-85-ACa had a small apparent number of micron-sized particles, which may be indicative of extensive protein aggregation having occurred during pre-heating of the whey protein component (Fig. 3). The polydispersity index of the unheated model IMF samples generally increased with increasing severity of pre-heat treatment of the whey protein, with H-85-ACa displaying a significantly higher polydispersity than any of the other samples. Following HTST heat treatment of the model IMF samples, the mean particle size ranged from 204 to $278 \mathrm{~nm}$ and all samples, excluding H-85-ACa, demonstrated a small second peak constituting particles 


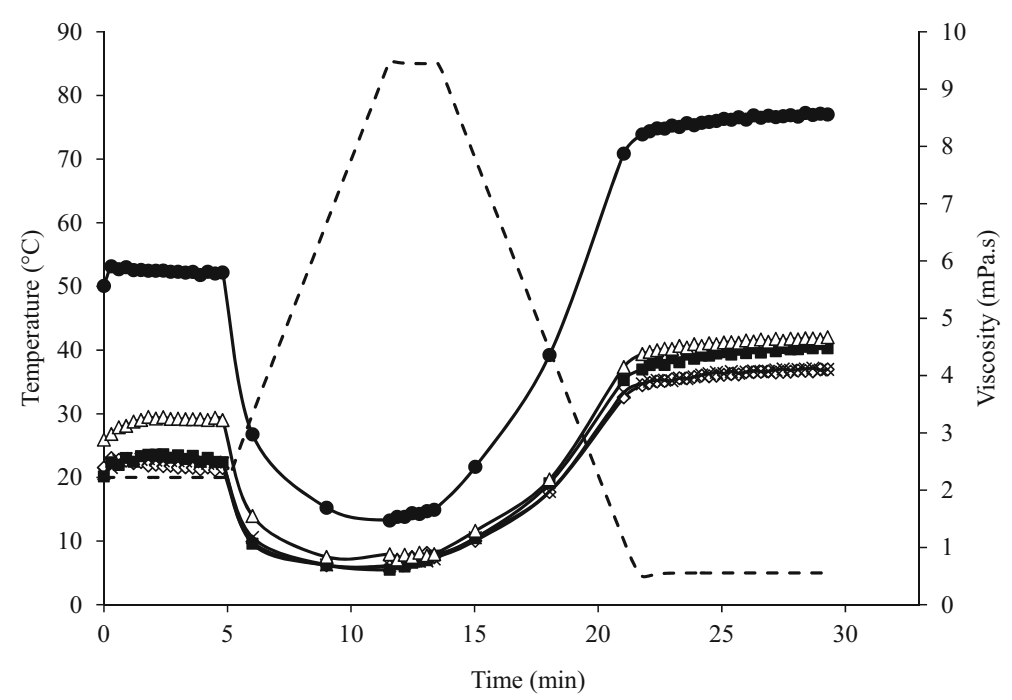

Fig. 2 Temperature (dashed line) and viscosity (symbols) during lab-scale high-temperature short-time treatment of model IMF samples prepared with whey protein treated as follows: unheated control (UH-C, $\checkmark$ ), unheated control with calcium added (UH-C-Ca, - - $)$ and samples heated at $72{ }^{\circ} \mathrm{C}$ before calcium was added $(\mathrm{H}-72-\mathrm{BCa}, *)$, heated at $85^{\circ} \mathrm{C}$ before calcium was added $(\mathrm{H}-85-\mathrm{BCa},-\triangle)$ ) or heated at $85{ }^{\circ} \mathrm{C}$ with added calcium (H-85-ACa, - - . Results are the means of data from three independent trials

ranging in size from 50 to $100 \mathrm{~nm}$. The micron-sized particles that were evident in the H-85-ACa IMF sample before heating increased in number following HTST treatment, and micron-sized particles were also evident in the UH-C-Ca and H-85BCa samples (Fig. 3b). An increased polydispersity index was also observed in all samples following HTST treatment but the differences between samples were not significant (Table 2).

\subsection{Denaturation of whey proteins}

Before heating of the model IMF samples, the levels of total whey protein denaturation in samples H-72-BCa, H-85-BCa and H-85-ACa were 25.5, 74.8 and 78.1\%, respectively; thus, the levels of denaturation increased as the severity of the pre-heat treatment of the whey protein increased, as expected, while pre-heat treatment of the whey protein component at $85{ }^{\circ} \mathrm{C}$, in the presence of $2.2 \mathrm{mM}$ added calcium, resulted in higher $(P<0.05)$ levels of denaturation. Upon HTST of the model IMF systems, total denaturation levels in the samples UH-C and UH-C-Ca were 81.2 and $82.4 \%$, respectively, and levels of denaturation were slightly higher in model IMF systems where the whey protein component had been pre-heat treated at 72 or $85^{\circ} \mathrm{C}$ (i.e. $84.3,87.3$ and $86.1 \%$ for $\mathrm{H}-72-\mathrm{BCa}, \mathrm{H}-85-\mathrm{BCa}$ and $\mathrm{H}-85-\mathrm{ACa}$, respectively).

Reversed-phase high-performance liquid chromatography (RP-HPLC) was used to quantify denaturation of the individual whey protein fractions in the model IMF samples before and after HTST (Table 3). The levels of denaturation of $\beta-\lg$ were generally higher than those for $\alpha$-lac on HTST processing of the model IMF solutions 


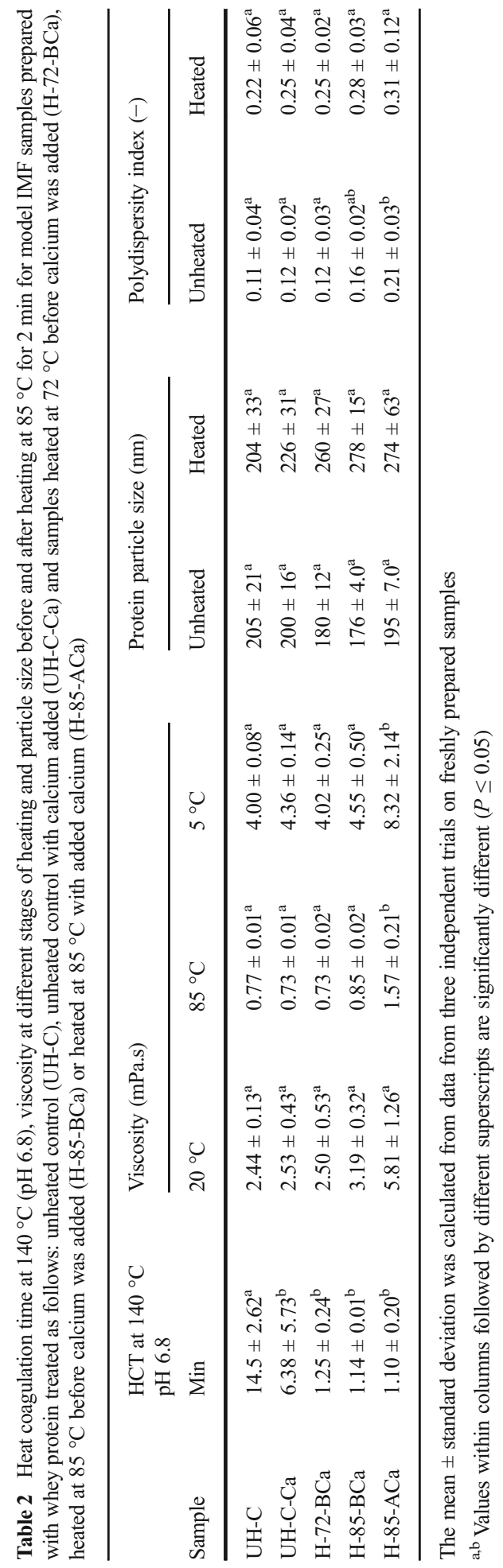



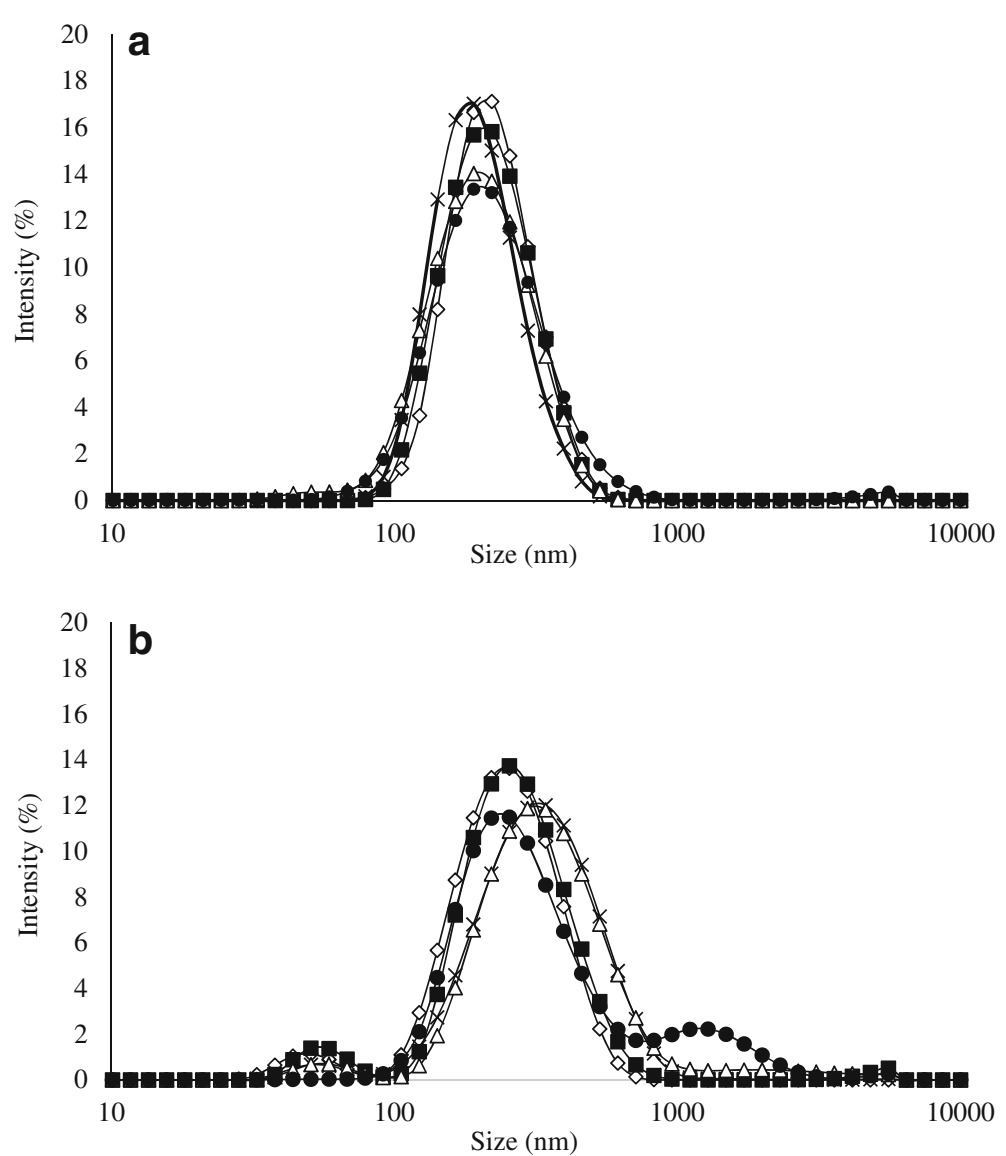

Fig. 3 Particle size distribution [a] before and [b] after lab-scale HTST treatment of model IMF samples prepared with whey protein treated as follows: unheated control (UH-C, $\diamond-$ ), unheated control with calcium added (UH-C-Ca, - ) and samples heated at $72{ }^{\circ} \mathrm{C}$ before calcium was added (H-72-BCa, $*$ ), heated at $85^{\circ} \mathrm{C}$ before calcium was added $(\mathrm{H}-85-\mathrm{BCa},-\triangle)$ ) or heated at $85^{\circ} \mathrm{C}$ with added calcium $(\mathrm{H}-85-\mathrm{ACa},-\mathbf{-})$. Results are the means of data from three independent trials

following pre-treatment of the whey protein fraction at 72 or $85^{\circ} \mathrm{C}$. Following HTST treatment, the extent of denaturation of $\beta$-lg in all five model IMF samples was $\geq 94.7 \%$, with the level of denaturation increasing with pre-heating temperature of the whey protein component; samples $\mathrm{H}-85-\mathrm{BCa}$ and $\mathrm{H}-85-\mathrm{ACa}$ had significantly higher levels of denaturation ( $98 \%$ ) than any of the other samples.

The effect of pre-heat treatment on denaturation of $\alpha$-lac during subsequent HTST treatment of model IMF solutions was even more pronounced than for the $\beta$-lg fraction. For both UH-C and UH-C-Ca, in which the whey protein fraction had not been pre-heat treated, the levels of denaturation were 78.0 and $76.2 \%$, respectively, after HTST treatment of the model IMF systems. Sample H-72-BCa had an $\alpha$-lac denaturation level of $82.8 \%$, which was significantly higher than that of the UH-C sample, and in the model IMF system containing whey protein which had been pre-heat treated at $85^{\circ} \mathrm{C}$, the levels of denaturation in the corresponding model IMF solutions were significantly higher, at 94.0 and $94.2 \%$, for the H-85-ACa and H-85-BCa samples. 


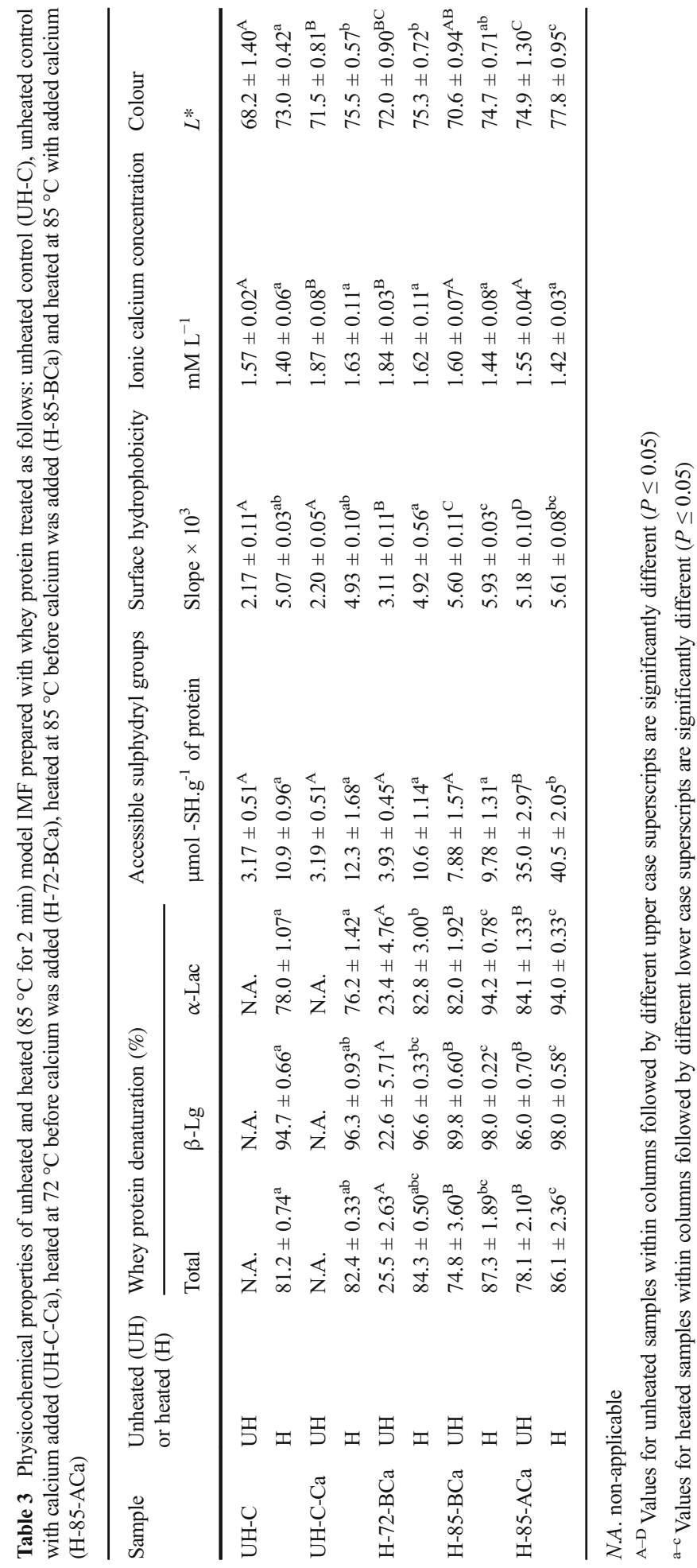




\subsection{Surface reactivity of proteins}

\subsubsection{Accessible sulphydryl (-SH) groups}

Low levels of accessible -SH groups were present in the UH-C and UH-C-Ca samples, i.e. 3.17 and $3.19 \mu \mathrm{mol}-\mathrm{SH} . \mathrm{g}^{-1}$ protein, respectively, as expected due to the relatively compact globular structure of native whey protein molecules. When WPI was preheated at $72{ }^{\circ} \mathrm{C}$, the concentration of accessible -SH groups in $\mathrm{H}-72-\mathrm{BCa}$ increased to $3.93 \mu \mathrm{mol}-\mathrm{SH} . \mathrm{g}^{-1}$ protein. On pre-heating of the whey protein component at $85{ }^{\circ} \mathrm{C}$, sample $\mathrm{H}-85-\mathrm{BCa}$ had a higher level of accessible $-\mathrm{SH}$ groups $\left(7.88 \mu \mathrm{mol}-\mathrm{SH}^{-g^{-1}}\right.$ of protein) compared to UH-C. On pre-heating at $85^{\circ} \mathrm{C}$, there was extensive denaturation of whey proteins (Table 3) with the exposure of previously-buried reactive functional groups. Accessible -SH groups were thus significantly more accessible in the H-85ACa sample compared to the UH-C sample, with significantly higher levels of $35.0 \mu \mathrm{mol}-\mathrm{SH} . \mathrm{g}^{-1}$ of protein measured for the former.

Following HTST, the levels of accessible -SH groups were higher in all IMF samples compared to their respective unheated samples, while H-85-ACa was significantly higher in the concentration of accessible -SH groups compared to HTST-treated UH-C (Table 3).

\subsubsection{Surface hydrophobicity}

Prior to HTST treatment of the model IMF solutions, the UH-C and UH-C-Ca samples had surface hydrophobicity $\left(S_{0}\right)$ values of $2.17 \times 10^{3}$ and $2.20 \times 10^{3}$, respectively. In general, as the temperature of pre-heat treatment applied to the whey protein component increased, the surface hydrophobicity also increased, indicating the exposure of previously buried hydrophobic regions as a result of whey protein denaturation (Table 3). When the model IMF samples were subsequently HTST-treated, surface hydrophobicity of all samples were higher than that of the UH-C sample, but there were no significant differences between samples UH-C, UH-C-Ca and H-72-BCa. Preheating of whey protein at $85{ }^{\circ} \mathrm{C}$ resulted in greater exposure of hydrophobic regions than at $72{ }^{\circ} \mathrm{C}$. In the $\mathrm{H}-85-\mathrm{BCa}$ sample, the $S_{(0)}$ value was $5.93 \times 10^{3}$ while that for $\mathrm{H}-85$-ACa was slightly lower, at $5.61 \times 10^{3}$.

\subsection{Colour}

There were significant differences in $L^{*}$ value of unheated model IMF samples; as preheat temperature applied to the whey protein component increased the $L^{*}$ value of the IMF solutions generally increased. Upon HTST treatment, the $L^{*}$ value was higher in all model IMF samples than that of the respective unheated samples.

\subsection{Sedimentable protein profile before and after heating}

Ultracentrifugation was applied to separate the colloidal and soluble phases, and proteins therein of model IMF samples before and after heating. As pre-treatment temperature increased, the level of $\mathrm{K}$-casein in the ultracentrifugation supernatants of the unheated and heated IMF samples generally increased (Table 4). As a general trend, 
Table 4 The level (\% of total peak area) of each individual protein fraction; $\mathrm{k}$-casein, $\beta$-lactoglobulin $(\beta$-lg) and $\alpha$-lactalbumin $(\alpha$-lac), in ultracentrifugal supernatants of model IMF samples prepared with whey protein treated as follows: unheated control (UH-C), unheated control with calcium added (UH-C-Ca) and samples heated at $72{ }^{\circ} \mathrm{C}$ before calcium was added (H-72-BCa), heated at $85^{\circ} \mathrm{C}$ before calcium was added (H-85-BCa) or heated at $85^{\circ} \mathrm{C}$ with added calcium (H-85-ACa)

\begin{tabular}{|c|c|c|c|c|c|c|c|c|}
\hline \multirow[t]{2}{*}{ Sample } & \multirow[b]{2}{*}{$\begin{array}{l}\text { Total } \\
\text { protein } \\
\%\end{array}$} & \multicolumn{3}{|l|}{ Unheated } & \multicolumn{4}{|l|}{ Heated } \\
\hline & & \multicolumn{3}{|c|}{$\%$ of total protein* } & $\begin{array}{l}\text { Total } \\
\text { protein } \\
\%\end{array}$ & \multicolumn{2}{|c|}{$\%$ of total protein* } & $\alpha-\mathrm{Lac}$ \\
\hline $\mathrm{UH}-\mathrm{C}$ & 3.50 & $1.1 \pm 1.2^{\mathrm{a}}$ & $72.7 \pm 0.8^{\mathrm{a}}$ & $26.2 \pm 0.9^{\mathrm{a}}$ & 3.00 & $7.5 \pm 2.1^{\mathrm{a}}$ & $66.0 \pm 0.9^{\mathrm{a}}$ & $26.4 \pm 2.4^{\mathrm{a}}$ \\
\hline UH-C-Ca & 3.41 & $0.9 \pm 1.2^{\mathrm{a}}$ & $72.7 \pm 1.0^{\mathrm{a}}$ & $26.3 \pm 0.7^{\mathrm{a}}$ & 2.10 & $8.7 \pm 5.5^{\mathrm{a}}$ & $63.3 \pm 8.0^{\mathrm{a}}$ & $28.0 \pm 2.6^{\mathrm{a}}$ \\
\hline H-72-BCa & 3.42 & $6.4 \pm 4.8^{\mathrm{a}}$ & $67.6 \pm 5.7^{\mathrm{ab}}$ & $26.0 \pm 1.4^{\mathrm{a}}$ & 3.38 & $9.0 \pm 1.5^{\mathrm{a}}$ & $64.1 \pm 3.6^{\mathrm{ab}}$ & $26.9 \pm 2.2^{\mathrm{a}}$ \\
\hline $\mathrm{H}-85-\mathrm{BCa}$ & 3.38 & $5.1 \pm 3.9^{\mathrm{a}}$ & $68.3 \pm 3.2^{\mathrm{a}}$ & $26.6 \pm 3.4^{\mathrm{a}}$ & 2.96 & $7.8 \pm 4.3^{\mathrm{a}}$ & $64.6 \pm 3.4^{\mathrm{a}}$ & $27.6 \pm 5.3^{\mathrm{a}}$ \\
\hline $\mathrm{H}-85-\mathrm{ACa}$ & 1.40 & $6.5 \pm 2.7^{\mathrm{a}}$ & $58.9 \pm 3.1^{\mathrm{b}}$ & $34.6 \pm 2.0^{\mathrm{b}}$ & 1.13 & $12.3 \pm 2.8^{\mathrm{a}}$ & $49.7 \pm 7.2^{\mathrm{b}}$ & $38.0 \pm 9.1^{\mathrm{a}}$ \\
\hline
\end{tabular}

Values are mean peak areas determined at $214 \mathrm{~nm}$ by reversed-phase high-performance liquid chromatography, before and after heating at $85{ }^{\circ} \mathrm{C}$ for $2 \min (\mathrm{pH} 6.8)$

*Calculated as $\%$ of total peak area for $\mathrm{K}$-casein, $\beta$-lg and $\alpha$-lac

${ }^{\mathrm{a}, \mathrm{b}}$ Values within column followed by different superscripts are significantly different $(P \leq 0.05)$

as K-casein levels increased in supernatants of both unheated and heated IMF samples, the levels of $\beta$-lg in the supernatants decreased. In the model IMF samples before HTST treatment, the levels of $\beta-\lg$ in the supernatants ranged from 67.6 to $72.7 \%$ for samples UH-C, UH-C-Ca, H-72-BCa and $\mathrm{H}-85-\mathrm{BCa}$, while they were significantly lower, at $58.9 \%$, for sample H-85-ACa. The supernatants of model IMF samples before HTST treatment had levels of $\alpha$-lac ranging from 26.0 to $26.6 \%$, except for the sample $\mathrm{H}-85-\mathrm{ACa}$, which had a significantly higher level (34.6\%) of $\alpha$-lac.

Upon HTST treatment of the model IMF samples, the levels of $k$-casein in supernatants were higher than those of the respective unheated samples and ranged from 7.5 to $12.3 \%$, while $\beta$-lg levels ranged from 49.7 to $66.0 \%$. $\alpha$-Lac levels in the supernatants also increased slightly as the temperature of the pre-heat treatment applied to the whey protein component increased, with H-85-ACa having a considerably higher level (38\%) of $\alpha$-lac than any of the other samples. These results suggest that the denatured $\beta-\lg$ in the pre-treated whey protein ingredients, and that formed during HTST treatment of the model IMFs, associates with K-casein through disulphide linkages.

Size-exclusion chromatography was used to classify the types of aggregates that were formed and the effect of pre-treatment of WPI on the molecular weight distribution of the aggregates found in the soluble phase of IMF supernatants. Prior to HTST treatment, a molecular weight profile equivalent to a whey protein:casein ratio of 60:40 was seen in the supernatant of UH-C (column 1), consistent with a significant proportion of the caseins ( $40 \%)$ being found in the insoluble material (Fig. 4). Generally, as pre-heating temperature increased, the concentration of low molecular weight proteins in the supernatants was reduced, while the presence of medium and high molecular weight material was increased, with considerably higher levels of insoluble material in H-85-ACa compared to UH-C. After HTST processing, the effect of calcium addition was evident in UH-C-Ca, in which the level of insoluble material was increased 


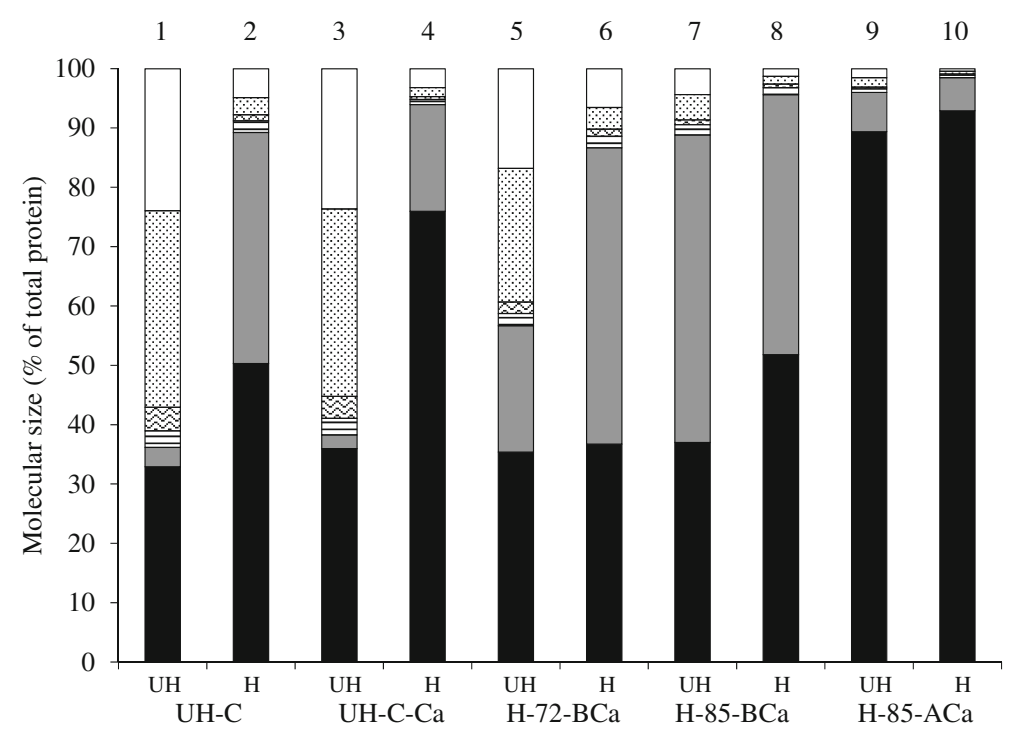

Fig. 4 The molecular weight distribution of soluble aggregates formed in ultracentrifugal supernatants of model IMF samples prepared with whey protein treated as follows: unheated control (UH-C), unheated control with calcium added (UH-C-Ca) and samples heated at $72{ }^{\circ} \mathrm{C}$ before calcium was added (H-72-BCa), heated at $85^{\circ} \mathrm{C}$ before calcium was added $(\mathrm{H}-85-\mathrm{BCa})$ or heated at $85^{\circ} \mathrm{C}$ with added calcium $(\mathrm{H}-85-\mathrm{ACa})$, measured both before $(\mathrm{UH})$ and after $(\mathrm{H})$ heating at $85^{\circ} \mathrm{C}$ for $2 \mathrm{~min}$, calculated from the peaks eluted by size exclusion chromatography. The total $(100 \%)$ is $5.2 \%$ initial protein concentration. Size fractions represent $8-15 \mathrm{~kg} . \mathrm{mol}^{-1}$

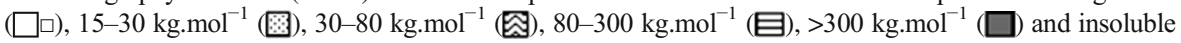
material (ロ). Column numbering refers to sample reference in text

compared to UH-C. There was a high proportion of large soluble aggregates present in sample $\mathrm{H}-72-\mathrm{BCa}$, while the level of insoluble material was similar to that in UH-C, suggesting that pre-treating at a low temperature can control aggregate size. Sample H-85-ACa showed the highest volume of insoluble material, at $90 \%$, which is in agreement with the earlier data showing significantly higher viscosity (Table 2, Fig. 2) and PSD (Table 2, Fig. 3) for that sample compared to the other IMF samples.

\section{Discussion}

This study demonstrates that pre-denaturation and/or aggregation, to varying extents, of whey protein, has a substantial effect on the physicochemical properties of nutritional protein systems during HTST thermal processing. This was seen from the effects of pre-heating temperature and ionic strength (i.e. level of added calcium ions) during preheat treatment of a whey protein isolate ingredient used in the formulation of a model IMF system, which gave different levels of denaturation and/or aggregation in the whey protein ingredient. These differences in denaturation and aggregation state of the whey protein ingredient greatly influenced the physicochemical properties (e.g. particle size and viscosity) of the model IMF system. These differences in physicochemical properties of the model IMF system during thermal processing were influenced mainly by differences in protein-protein interactions, primarily between $\beta$-lg and $\kappa$-casein during 
heat treatment of the model IMF system, as affected by pre-heat treatment of the whey protein ingredient component of the formulation.

In this study, the levels of all compositional parameters were maintained constant between samples except for calcium concentration (Table 1). The presence of calcium is known to promote aggregation of whey proteins during thermal processing and generally reduce stability to heating and, thus, as expected, the heat coagulation time of the model IMF formulations, as measured at $140{ }^{\circ} \mathrm{C}$ and $\mathrm{pH} 6.8$, was considerably lower in the systems formulated with added calcium. All samples in which the whey protein component had been pre-heat treated, at either 72 or $85^{\circ} \mathrm{C}$, with added calcium or to which calcium was added after pre-treatment, had very low heat coagulation times, of $<2$ min (Table 2). Both De Kort et al. (2012) and Crowley et al. (2014b) previously reported the negative effects of high $\mathrm{Ca}$ ion concentration on the heat stability of milk protein systems.

Anema and $\mathrm{Li}$ (2003) reported that the association of whey proteins with casein micelles on heating is strongly dependent on milk $\mathrm{pH}$ and that the level of association decreased from $\sim 70 \%$ at $\mathrm{pH} 6.5$ to about $32 \%$ at $\mathrm{pH}$ 6.7. The model IMF systems used in this study were adjusted to $\mathrm{pH} 6.8$, which is a typical mid-range $\mathrm{pH}$ used for infant formula processing. The denaturation temperatures of $\beta-\lg$ and $\alpha$-lac are 62 and $78{ }^{\circ} \mathrm{C}$, respectively, and Kehoe et al. (2011) suggested that the presence of $\alpha$-lac increased the rate of $\beta$-lg denaturation, even though $\alpha$-lac does not contain a free sulfhydryl group, and it has been shown to be involved in the formation of hetero- and homo-aggregates in the presence of $\beta$-lg via disulphide interchange reactions.

Simmons et al. (2007) reported that, on heating of whey protein concentrate systems at 70 and $75^{\circ} \mathrm{C}$, small and reversible bonds were formed between protein particles due to weak van der Waal interactions, while covalent disulphide bonds were strengthened at higher temperatures, e.g. 80 and $90{ }^{\circ} \mathrm{C}$. These authors also reported that, in the presence of calcium, protein aggregates were formed on the surface of the whey protein particles. For these reasons, it was important to evaluate the size and surface reactivity of protein particles/aggregates formed in the model IMF systems in this study as influenced by pre-denaturation and aggregation of the whey protein component of the formulations.

In general, as the temperature of pre-heating of the whey protein raw material (i.e. WPI solution) increased, the levels of denaturation in the formulated model IMF solutions increased. Whey protein heated at high ionic strength (i.e. containing $2.2 \mathrm{mM}$ added calcium) had slightly higher levels of whey protein denaturation and larger particle size, indicating that calcium was involved in the aggregation mechanism; it is known that addition of calcium ions to whey protein solutions lowers the whey protein denaturation temperature and favours aggregate formation (Mulvihill and Donovan, 1987, Simmons et al., 2007). The lower $\mathrm{Ca}^{2+}$ ion concentration after HTST at $85{ }^{\circ} \mathrm{C}$ further suggests that calcium was involved in the formation of high molecular weight protein aggregates, as it is known to have three roles in thermal denaturation and aggregation: (1) formation of intermolecular protein- $\mathrm{Ca}^{2+}$-protein bridges, (2) intermolecular electrostatic shielding of negatively-charged protein molecules and (3) ion-induced changes that lead to hydrophobic interactions and aggregation of whey proteins at high temperatures (Petit et al., 2011). While the increase in $L^{*}$ value on HTST treatment of samples with added calcium supports the hypothesis that addition of calcium results in the production of larger aggregates (Table 2) with greater 
light-scattering ability; this is consistent with the report of Marangoni et al. (2000) that the addition of calcium to a whey protein system induced formation of large aggregates and caused an opaque appearance of cold-set gels. This is further evident from the observation that, for the model IMF formulations containing whey protein pre-heated at $85^{\circ} \mathrm{C}$, the denaturation levels of $\alpha$-lac were similar to those of $\beta$-lg, as $\alpha$-lac has been reported to irreversibly denature and aggregate only when in the presence of $\beta-\lg$ and calcium (Chaplin and Lyster, 1986). There was also an increase in the surface reactivity of the protein molecules/aggregates in the unheated model IMF solutions as the temperature of pre-heating applied to the whey protein component increased; this was shown by significant $(P<0.05)$ increases in the concentrations of accessible SH groups and surface hydrophobicity on denaturation and unfolding of whey proteins (Table 3). Upon subsequent HTST treatment of the model IMF samples, the concentration of accessible -SH groups and surface hydrophobicity increased for all samples, but the differences between samples were small compared with the differences between samples prior to HTST treatment of the IMF systems, and the differences were largely not significant $(P>0.05)$.

The pre-treatment of whey protein can affect protein-protein interactions during subsequent heat treatment of IMF, and complexes can form between the whey proteins themselves or whey proteins and caseins. Thus, after HTST treatment, the model IMF systems are composed of a mixture of three types of whey proteins: native whey proteins, soluble whey protein aggregates and aggregates that have associated with the surface of the casein micelle (Taterka and Castillo, 2015). This can influence the physicochemical properties of the model IMF, and it is important to categorise the type of aggregates that are formed. Overall, the levels of $\beta$-lg decreased and the levels of $\mathrm{K}$ casein increased in the ultracentrifugal supernatants of IMF samples (Table 4), as denatured $\beta-\lg$ can associate with $\mathrm{K}$-casein at the surface of the casein micelle and $\mathrm{K}$ casein may also dissociate from the micelle on heating and form soluble complexes with $\beta$-lg (Donato and Guyomarc'h, 2009, Donato et al., 2007). The formation of whey protein-casein micelle interactions was evident from increases in particle size on heating of the model IMF samples (Table 2, Fig. 3); the mean particle size in all model IMF samples increased during HTST treatment, with a small second peak of particles of size $50-100 \mathrm{~nm}$ (Fig. 3b) forming. Since it is known that K-casein is the only casein fraction that forms complexes with denatured whey protein (Donato and Dalgleish, 2006), it may be concluded that changes in particle size due to the formation of aggregates were related to interactions between $\mathrm{K}$-casein and whey protein molecules/ aggregates.

The small proportion of larger, micron-sized particles, in the highly pre-denatured and aggregated sample (H-85-ACa) following HTST treatment, was indicative of more extensive protein-protein interactions and corresponded with the significantly higher viscosity (Table 2, Fig. 2) of this sample, compared to any of the other model IMF samples after HTST treatment. There were no significant differences $(P<0.05)$ in the levels of whey protein denaturation between samples $\mathrm{H}-85-\mathrm{BCa}$ and $\mathrm{H}-85-\mathrm{ACa}$, while the viscosity of the latter was significantly $(P<0.05)$ higher. These results were similar to those of Anema and Li (2003), who reported that the casein micelles in milk increased in size as a consequence of heat treatment at temperatures of $70-100{ }^{\circ} \mathrm{C}$ for up to $60 \mathrm{~min}$. That study demonstrated a correlation between the micelle size and the level of associated protein, indicating that the association of denatured whey 
proteins with the casein micelle surface influences the changes in protein particle size and that the heating conditions affected the extent of denaturation.

From analysis of the molecular weight distribution of the soluble protein aggregates by size-exclusion chromatography (Fig. 4), three important observations were made: (1) heating a model IMF that contained mainly native whey protein resulted in the production of much larger MW aggregates in the presence of added calcium, which can be seen in UH-C-Ca (column 4) compared to unheated UH-C (column 1); (2) preheating-induced denaturation of whey protein resulted in the production of smaller MW protein aggregates in the model IMF systems made using these ingredients, as seen in HTST-treated samples H-72-BCa (column 6) and H-85-BCa (column 8) compared to UH-C-Ca (column 4); and (3) pre-heating whey protein at $85{ }^{\circ} \mathrm{C}$ in the presence of added $\mathrm{Ca}$ resulted in the production of very large, mostly insoluble, whey protein aggregates in the H-85-ACa sample prior to HTST (column 9), with very little change in MW distribution of protein aggregates after HTST treatment of the model IMF system (column 10). These observations confirm that, due to the pre-denaturation and/ or aggregation of whey protein, there was an increase in number of larger aggregates and insoluble material after heating, which was evident from the PSD (Table 2, Fig. 3) and viscosity results (Table 2, Fig. 2).

\section{Conclusion}

The contributions of denaturation and aggregation of whey proteins during the manufacture of whey protein ingredients, as applied to the processing of model infant formula protein systems, were successfully separated and studied systematically. Extensive whey protein denaturation was readily achieved by pre-heating of whey protein solutions, while aggregation was promoted by the addition of low levels of calcium ions prior to HTST. Altering pre-heating temperature and calcium concentration prior to heating was effective in producing pre-heat-treated whey protein molecules/particles with very different surface reactivity, as shown by differences in levels of accessible SH groups and surface hydrophobicity. Increasing HTST temperature and calcium concentration generally increased the levels of denaturation and aggregation, with aggregation of whey proteins contributing most strongly to increases in protein particle size. The viscosity of model IMF systems during HTST thermal processing was more strongly influenced by size and reactivity of protein molecules/particles, than the extent of denaturation. Overall, pre-heat treatment of whey protein used in the formulation of model IMF systems helped to reduce the susceptibility of the whey protein to aggregation when incorporated into a model IMF protein system. In conclusion, this work has shown that the physical state/reactivity of whey protein molecules/particles strongly influences protein-protein interactions and their ability to contribute to viscosity during thermal processing, even at similar levels of denaturation. These findings are important in facilitating an enhanced understanding of protein-protein interactions and their influence on viscosity development and processing performance of formulated nutritional beverages such as infant formula.

Acknowledgments The authors would like to acknowledge the financial support provided by the Food Institutional Research Measure (FIRM) initiative of the Irish Department of Agriculture, Food and the Marine 
(project number 10/RD/ProSurf/TMFRC/723) and also Mr. Bernard Corrigan, Teagasc Food Research Centre, Moorepark, Fermoy, Co. Cork, for the assistance with mineral analysis by ICP-MS.

\section{References}

Alizadeh-Pasdar N, Li-Chan EC (2000) Comparison of protein surface hydrophobicity measured at various $\mathrm{pH}$ values using three different fluorescent probes. J Agr Food Chem 48:328-334

Anema SG (1997) The effect of chymosin on K-casein-coated polystyrene latex particles and bovine casein micelles. Int Dairy J 7:553-558

Anema SG, Li Y (2003) Association of denatured whey proteins with casein micelles in heated reconstituted skim milk and its effect on casein micelle size. J Dairy Res 70:73-83

Brodkorb A, Croguennec T, Bouhallab S, Kehoe JJ (2016) Heat-induced denaturation, aggregation and gelation of whey proteins. In: McSweeney PLH, O’Mahony JA (eds) Advanced Dairy Chemistry, 4th edn. Springer Science+Business Media, New York

Chaplin LC, Lyster RLJ (1986) Irreversible heat denaturation of bovine alpha-lactalbumin. J Dairy Res 53: 249-258

Crowley SV, Kelly AL, O’Mahony JA (2014a) Fortification of reconstituted skim milk powder with different calcium salts: impact of physicochemical changes on stability to processing. Int J Dairy Technol 67:474 482

Crowley SV, Megemont M, Gazi I, Kelly AL, Huppertz T, O’Mahony JA (2014b) Heat stability of reconstituted milk protein concentrate powders. Int Dairy J 37:104-110

Crowley SV, Caldeo V, McCarthy NA, Fenelon MA, Kelly AL, O’Mahony JA (2015a) Processing and protein fractionation characteristics of different polymeric membranes during filtration of skim milk at refrigeration temperatures. Int Dairy J 48:23-30

Crowley SV, O'Callaghan TF, Kelly AL, Fenelon MA, O’Mahony JA (2015b) Use of ultrafiltration to prepare a novel permeate for application in the functionality testing of infant formula ingredients. Sep Purif Technol 141:294-300

Crowley SV, Dowling AP, Caldeo V, Kelly AL, O’Mahony JA (2016) Impact of $\alpha$-lactalbumin: $\beta$ lactoglobulin ratio on the heat stability of model infant milk formula protein systems. Food Chem 194: 184-190

Davies TJ, Henstridge SC, Gillham CR, Wilson DI (1997) Investigation of whey protein deposit properties using heat flux sensors. Food Bioprod Process 75:106-110

De Kort E, Minor M, Snoeren T, van Hooijdonk T, van der Linden E (2012) Effect of calcium chelators on heat coagulation and heat-induced changes of concentrated micellar casein solutions: the role of calciumion activity and micellar integrity. Int Dairy J 26:112-119

Donato L, Dalgleish DG (2006) Effect of the $\mathrm{pH}$ of heating on the qualitative and quantitative compositions of the sera of reconstituted skim milks and on the mechanisms of formation of soluble aggregates. J Agric Food Chem 54:7804-7811

Donato L, Guyomarc'h F (2009) Formation and properties of the whey protein/K-casein complexes in heated skim milk - a review. Dairy Sci Technol 89:3-29

Donato L, Guyomarc'h F, Amiot S, Dalgleish DG (2007) Formation of whey protein/K-casein complexes in heated milk: preferential reaction of whey protein with $\mathrm{K}$-casein in the casein micelles. Int Dairy $\mathrm{J} 17$ : 1161-1167

Drapala KP, Auty MAE, Mulvihill DM, O’Mahony JA (2016) Improving thermal stability of hydrolysed whey protein-based infant formula emulsions by protein-carbohydrate conjugation. Food Res Int. doi:10.1016/j.foodres.2016.01.028

Eugenia Lucena M, Alvarez S, Menéndez C, Riera FA, Alvarez R (2006) Beta-lactoglobulin removal from whey protein concentrates: production of milk derivatives as a base for infant formulas. Sep Purif Technol 52:310-316

Herwig N, Stephan K, Panne U, Pritzkow W, Vogl J (2011) Multi-element screening in milk and feed by SFICP-MS. Food Chem 124:1223-1230

Hoffmann MAM, van Mil JJM (1997) Heat-induced aggregation of $\beta$-lactoglobulin: role of the free thiol group and disulfide bonds. J Agr Food Chem 45:2942-2948

Huppertz T, Fox PF, Kelly AL (2004) High pressure-induced denaturation of alpha-lactalbumin and betalactoglobulin in bovine milk and whey: a possible mechanism. J Dairy Res 71:489-495 
IDF (2014) International IDF standard $20 \mathrm{~A}$. In: Milk and milk products - determination of nitrogen contentpart 1: Kjeldahl principle and crude protein calculation. International Dairy Federation, Brussels

Kehoe JJ, Wang L, Morris ER, Brodkorb A (2011) Formation of non-native $\beta$-lactoglobulin during heatinduced denaturation. Food Biophys 6:487-496

Madureira AR, Tavares T, Gomes AMP, Pintado ME, Malcata FX (2010) Invited review: physiological properties of bioactive peptides obtained from whey proteins. J Dairy Sci 93:437-455

Marangoni AG, Barbut S, McGauley SE, Marcone M, Narine SS (2000) On the structure of particulate gelsthe case of salt-induced cold gelation of heat-denatured whey protein isolate. Food Hydrocoll 14:61-74

Mulcahy EM, Mulvihill DM, O’Mahony JA (2016) Physicochemical properties of whey protein conjugated with starch hydrolysis products of different dextrose equivalent values. Int Dairy J 53:20-28

Mulvihill DM, Donovan M (1987) Whey proteins and their thermal denaturation-a review. Irish J Food Sci Tech 11:43-75

O'Kennedy BT, Mounsey JS (2006) Control of heat-induced aggregation of whey proteins using casein. J Agric Food Chem 54:5637-5642

Oldfield DJ, Singh H, Taylor MW, Pearce KN (1998) Kinetics of denaturation and aggregation of whey proteins in skim milk heated in an ultra-high temperature (UHT) pilot plant. Int Dairy J 8:311-318

Ooi JY 2015 Whey protein denaturation and aggregation during high temperature-short time thermal processing as influenced by temperature and ionic strength. MSc Degree, University College Cork

Permyakov EA, Berliner LJ (2000) $\alpha$-Lactalbumin: structure and function. FEBS Lett 473:269-274

Petit J, Herbig AL, Moreau A, Delaplace G (2011) Influence of calcium on $\beta$-lactoglobulin denaturation kinetics: implications in unfolding and aggregation mechanisms. J Dairy Sci 94:5794-5810

Roefs SPFM, de Kruif KG (1994) A model for the denaturation and aggregation of beta-lactoglobulin. Eur J Biochem 226:883-889

Ryan KN, Foegeding EA (2015) Formation of soluble whey protein aggregates and their stability in beverages. Food Hydrocoll 43:265-274

Ryan KN, Vardhanabhuti B, Jaramillo DP, van Zanten JH, Coupland JN, Foegeding EA (2012) Stability and mechanism of whey protein soluble aggregates thermally treated with salts. Food Hydrocoll 27:411-420

Schmitt C, Bovay C, Vuilliomenet A-M, Rouvet M, Bovetto L (2011) Influence of protein and mineral composition on the formation of whey protein heat-induced microgels. Food Hydrocoll 25:558-567

Simmons MJH, Jayaraman P, Fryer PJ (2007) The effect of temperature and shear rate upon the aggregation of whey protein and its implications for milk fouling. J Food Eng 79:517-528

Taterka H, Castillo M (2015) The effect of whey protein denaturation on light backscatter and particle size of the casein micelle as a function of $\mathrm{pH}$ and heat-treatment temperature. Int Dairy J 48:53-59

Verheul M, Roefs SPFM, de Kruif KG (1998) Kinetics of heat-induced aggregation of beta-lactoglobulin. J Agric Food Chem 46:896-903

Wijayanti HB, Bansal N, Deeth HC (2014) Stability of whey proteins during thermal processing: a review. Compr Rev Food Sci Food Saf 13:1235-1251 